\title{
Pleural mesothelioma and exposure to asbestos: evaluation from work histories and analysis of asbestos bodies in bronchoalveolar lavage fluid or lung tissue in 131 patients
}

\author{
J C Pairon, E Orlowski, Y Iwatsubo, M A Billon-Galland, G Dufour, S Chamming's, \\ C Archambault, J Bignon, P Brochard
}

\begin{abstract}
Exposure to asbestos was evaluated in 131 patients with pleural malignant mesothelioma in the Paris area between 1986 and 1992 using data from a detailed specific questionnaire and light microscopy analysis of the retention of asbestos bodies in bronchoalveolar lavage fluid or lung tissue. Probable or definite exposure to significant levels of asbestos dust was identified in only 48 (36.6\%) subjects, and significant asbestos body counts (above 1 asbestos body/ml in bronchoalveolar lavage fluid or 1000 asbestos bodies/g of dry lung tissue) were found in only $45(34 \cdot 3 \%)$ subjects. Overall 50 subjects had experienced exposure to only low levels of asbestos or no exposure at all and showed no significant retention of asbestos bodies in the biological sample analysed. Previous studies have shown that light microscopy may be useful in the identification of subjects with previous exposure to asbestos. In this study, apart from cases with obvious exposure to asbestos, a large group of subjects seemed to have a history of exposure or lung retention of asbestos bodies suggestive of very low levels of cumulative exposure, similar to those described in the general population.
\end{abstract}

(Occup Environ Med 1994;51:244-249)

Malignant mesothelioma has long been recognised as one of the most specific occupational cancers: epidemiological evidence has accumulated concerning the strong association between exposure to asbestos and the outcome of an excess of mesotheliomas in various occupational groups (reviewed by Gibbs $^{1}$; McDonald and McDonald; ${ }^{2}$ Brochard $e t \mathrm{al}^{3}$ ). Many authors have focused attention on the specific role of the type of asbestos fibres. Indeed, results of cohort studies suggested that similar levels of exposure to chrysotile or amphiboles led to many fewer mesotheliomas in subjects exposed to chrysotile than in groups exposed to mixed fibres or amphiboles. ${ }^{24}$ Moreover, results of analysis of lung tissue by electron microscopy in patients with mesothelioma suggested that amphiboles were the most often incriminated fibre types, especially crocidolite and amosite. ${ }^{25-10}$ Recently, one author reported a different pattern of respective capacities for inducing mesothelioma from asbestos fibres, ${ }^{11}$ suggesting that amosite was the most important, whereas chrysotile and crocidolite were much less often incriminated. Nevertheless, although the association with exposure to asbestos was indisputable when workers had been exposed to high levels of asbestos, the attention of the scientific community has more recently been drawn to mesothelioma occurring in subjects free of any significant exposure to asbestos or exposed to only low cumulative doses. ${ }^{12} 13$

From case-referent studies, the percentage of mesotheliomas without exposure to asbestos has been reported to vary from one study to another. ${ }^{3}$ The difficulties encountered in the use of data from occupational questionnaires when evaluating the level of previous exposure to asbestos have been underlined by some authors. ${ }^{14} 15$ Thus other alternative methods have been proposed. Characterisation and counting of asbestos bodies by light microscopy in bronchoalveolar lavage (BAL) fluid or lung tissue provide a good estimate of previous exposure to asbestos, especially in cases of interstitial diseases or pulmonary malignancies. ${ }^{16}{ }^{17} \mathrm{~A}$ good correlation has been reported between the concentration of asbestos bodies in BAL fluid and the parenchymal concentration of asbestos bodies. ${ }^{17}$ Thus asbestos dust load in the lung may be evaluated much more simply than with analysis by electron microscopy. Nevertheless, published reports of quantification of asbestos by light microscopy in biological samples of patients with malignant mesothelioma mainly concerned subjects who had experienced obvious exposure to asbestos. $^{18-23}$ Few studies have been performed in mesotheliomas occurring in regions without substantial concentration of specific asbestos related industries. ${ }^{24-26}$

The aim of our study was to characterise asbestos exposure of 131 patients with pleural malignant mesothelioma in the Paris area to estimate the proportion without significant exposure to asbestos. This was assessed with data from an occupational questionnaire and results of the quantification of asbestos bodies in BAL fluid or lung tissue. 


\section{Materials and methods}

STUDY POPULATION

Subjects included in the study were 116 cases of malignant mesothelioma from a casecontrol study on pleural malignant mesothelioma conducted in the Paris area between January 1987 and December $1992,{ }^{3}$ for whom a lung tissue sample or BAL fluid sample was available. During this period a total of 236 cases of malignant mesothelioma was recruited in the case-control study in the Paris area. Inclusion criteria were pleural localisation of the malignant mesothelioma, residence in the Paris area at the time of diagnosis, and having had a personal interview. Pneumology, chest surgery, and oncology departments provided most of the cases. All cases were reviewed by the French mesothelioma panel for histological confirmation of diagnosis. $^{27}$

Fifteen additional subjects were included who were diagnosed as having pleural mesothelioma at the Centre Hospitalier Intercommunal de Créteil between January 1986 and December 1992, for whom BAL fluid or a lung tissue sample was also available. Two subjects with associated primary lung carcinoma were excluded.

Overall, there were 115 men and 16 women. Their mean (range) age at diagnosis was $61.6(37-84)$ years. For all subjects, the diagnosis of malignant mesothelioma was confirmed histologically by the French mesothelioma panel.

\section{EVALUATION OF OCCUPATIONAL HISTORIES}

Complete occupational histories were collected by means of a standardised questionnaire adapted from Siemiatycki et al..$^{28}$ Each patient was interviewed personally about his work history, with specific questions concerning occupational, domestic, and environmental exposure to asbestos.

Occupational asbestos exposure of each job was rated by two of the authors (EO and GD), blind with respect to asbestos body count in BAL fluid or lung tissue. Evaluation took into account job title, job description, information about the work place, historical period, and subject's answers to open questions about exposure to asbestos. Three semiquantitative indices were used to assess exposure to asbestos for each job according to criteria defined elsewhere. ${ }^{15}$ These were probability of exposure, level of exposure, and frequency of exposure. These indices allowed division of the subjects into four broad classes of asbestos exposure (table 1). For each subject, the job with the highest level of exposure was used for classification. Only subjects whose occupational history included probable

Table 1 Definition of classes of asbestos exposure in the study population

\begin{tabular}{llll}
\hline $\begin{array}{l}\text { Class of } \\
\text { exposure }\end{array}$ & Probability of exposure & Level of exposure & Frequency of exposure \\
\hline 0 & Unlikely or possible & - & $-\overline{\text { An }}$ \\
1 & $\begin{array}{l}\text { Probable or definite } \\
2\end{array}$ & $\begin{array}{l}\text { Medium, high, very high } \\
\text { Probable or definite }\end{array}$ & $\begin{array}{l}\text { Sporadic } \\
\text { Discontinuous or } \\
\text { continuous }\end{array}$ \\
\hline
\end{tabular}

or definite exposure were considered to be exposed. The appendix lists the classification of the various types of jobs. The same job title applied to different subjects could sometimes be in a different class of asbestos exposure, depending on information reported in the questionnaire. For each subject, cumulative duration of exposure (independently of the level of exposure), time from the onset of exposure, and time since the last exposure were calculated.

ANALYSIS OF ASBESTOS BODIES IN BAL FLUID AND LUNG TISSUE

The BAL fluid and lung tissue samples were collected in cleaned flasks containing $10 \mathrm{ml}$ of $10 \%$ formalin (Prolabo, Paris, France). Specimens were prepared as described elsewhere. ${ }^{17}$ Quantification of asbestos bodies was by light microscopy (magnification $\times 250$ ). Only typical ferruginous bodies, as defined by Churg and Warnock, ${ }^{29}$ were assumed to be asbestos bodies. Concentrations of asbestos bodies were expressed as the number of asbestos bodies per ml of BAL fluid or per $g$ of dry lung tissue as appropriate. According to previous published threshold values, ${ }^{17} 30$ significant retention of asbestos bodies in the lung was defined as more than 1 asbestos body per $\mathrm{ml}$ in BAL fluid or 1000 asbestos bodies per $\mathrm{g}$ of dry lung tissue. Although some subjects had more than one sample, only one result is presented in the results section, with priority given to the result from the lung tissue sample.

\section{STATISTICAL METHODS}

Subjects were assigned to either a high retention group (HR) or a non-significant retention group (NSR), depending on comparison of the value of retention of asbestos bodies in the biological sample with the reference value. Non-parametric statistical tests were used for all comparisons. The Kruskal-Wallis $\mathrm{H}$ test was used to study the relation between class of exposure and quantitative variablesthat is, asbestos body retention in BAL fluid or lung sample, age, duration of exposure, time since the first exposure, and time since the end of the last exposure. The $\chi^{2}$ test was used to compare different classes of exposure according to the number of subjects showing significant retention of asbestos bodies in BAL fluid or lung tissue.

The relations between asbestos body concentration in biological samples and duration of asbestos exposure or time since the last exposure were evaluated by the Spearman correlation coefficient. All calculations were performed with SAS software.

\section{Results}

Table 2 shows the characteristics of the study population. Among the 131 subjects, 67 $(51 \cdot 1 \%)$ had experienced only low levels of exposure to asbestos or no exposure at all, as assessed by the occupational questionnaire (classes 0 and 1). A history of work entailing regular, probable, or definite exposure to at 
Table 2 Characteristics of patients with mesotheliomas

\begin{tabular}{|c|c|c|c|c|c|c|c|}
\hline & $\begin{array}{l}\text { No of } \\
\text { patients }\end{array}$ & Age & $\begin{array}{l}\text { Duration of } \\
\text { exposure }\end{array}$ & $\begin{array}{l}\text { Time since first } \\
\text { exposure }\end{array}$ & $\begin{array}{l}\text { Time since last } \\
\text { exposure }\end{array}$ & $\begin{array}{l}\text { Asbestos bodies/ml } \\
\text { of } B A L \text { fluid }\end{array}$ & $\begin{array}{l}\text { Asbestos bodies/g } \\
\text { of dry lung tissue }\end{array}$ \\
\hline $\begin{array}{l}\text { Whole sample: } \\
\text { Mean (SD) } \\
\text { Median (range) } \\
\text { Class 0: } \\
\text { Mean (SD) } \\
\text { Median (range) } \\
\text { Class 1: } \\
\text { Mean (SD) } \\
\text { Median (range) } \\
\text { Class 2: } \\
\text { Mean (SD) } \\
\text { Median (range) } \\
\text { Class 3: } \\
\text { Mean (SD) } \\
\text { Median (range) } \\
\text { p Valuef }\end{array}$ & 131 & $\begin{array}{l}61 \cdot 6(10 \cdot 8) \\
61(37-84) \\
63 \cdot 2(10 \cdot 6) \\
64(38-81) \\
\\
60 \cdot 7(12 \cdot 4) \\
59(37-83) \\
\\
63 \cdot 6(9 \cdot 9) \\
64(48-78) \\
60 \cdot 3(10 \cdot 3) \\
60 \cdot 5(41-84) \\
\text { NS }\end{array}$ & $\begin{array}{l}(\mathrm{n}=95) \\
17 \cdot 6(12 \cdot 1) \\
14(1-48) \\
- \\
- \\
15 \cdot 6(10 \cdot 5) \\
11(3-36) \\
17 \cdot 1(14 \cdot 6)^{\star} \\
10 \cdot 5(2-48) \\
18.9(12 \cdot 3) \\
16.5(1-41) \\
\text { NS }\end{array}$ & $\begin{array}{l}(\mathrm{n}=95) \\
38(12 \cdot 5) \\
37(12-70) \\
- \\
- \\
36 \cdot 5(13 \cdot 1) \\
35(12-63) \\
38 \cdot 9(15 \cdot 1) \\
40(16-62) \\
38 \cdot 7(11 \cdot 4) \\
40(15-70) \\
\text { NS }\end{array}$ & $\begin{array}{l}(\mathrm{n}=95) \\
19 \cdot 4(12 \cdot 9) \\
18(0-60) \\
- \\
- \\
21 \cdot 3(13 \cdot 8) \\
20(0-60) \\
21 \cdot 1(14 \cdot 3) \\
25(0-44) \\
17 \cdot 6(11 \cdot 7) \\
15 \cdot 5(0-45) \\
\mathrm{NS}\end{array}$ & $\begin{array}{c}(\mathrm{n}=95) \\
61 \cdot 9(554 \cdot 6) \\
0 \cdot 1(0-5400) \\
(\mathrm{n}=25) \\
0 \cdot 7(2 \cdot 4) \\
0(0-12) \\
(\mathrm{n}=22) \\
1 \cdot 8(5 \cdot 0) \\
0 \cdot 1(0-22) \\
(\mathrm{n}=9) \\
1 \cdot 4(2 \cdot 2) \\
0 \cdot 15(0-5 \cdot 8) \\
(\mathrm{n}=39) \\
149(864 \cdot 7) \\
0 \cdot 15(0-5400) \\
\text { NS }\end{array}$ & $\begin{array}{l}(n=36) \\
346532(1675641) \\
1365\left(0-10^{7}\right) \\
(n=11) \\
1028(1330) \\
381(0-4200) \\
(n=9) \\
9449(20637) \\
125(0-60000) \\
(n=7) \\
185409(474030) \\
317(0-1260000) \\
(n=9) \\
1230816(3304690) \\
6580\left(1130-10^{7}\right) \\
<0.05\end{array}$ \\
\hline
\end{tabular}

*Values indicated correspond to cumulative duration during which sporadic exposure to asbestos occurred. Thus real duration of exposure was generally largely overestimated in class 2 subjects, compared with class 1 and class 3 .

tLevel of significance with Kruskal-Wallis test. The four classes of exposure were compared for age and asbestos body count in BAL fluid or lung tissue, whereas only classes 1,2, and 3 were compared for duration of exposure, time since first exposure, and time since last exposure.

Calculations of mean, median, and range of values were performed on all subjects of each class of exposure. For asbestos body count in BAL fluid or lung tissue samples, the number of subjects with each type of biological sample is indicated in parentheses.

least medium levels of asbestos dusts (class 3) was found in only 48 subjects $(36 \cdot 6 \%)$. There was no statistical difference between the ages of the four groups at the time of diagnosis. Comparison of subjects in classes 1,2 , and 3 did not show any significant difference in the duration of exposure, time since the first exposure, and time since the last exposure.

When studying the whole population, asbestos body count in BAL fluid ranged from 0 to $5400 / \mathrm{ml}$, and in lung tissue from 0 to $10000000 / \mathrm{g}$ of dry lung tissue. Median values of asbestos bodies were 0.1 asbestos bodies/ml in BAL fluid and 1365 asbestos bodies/g of dry lung tissue (table 2). No sig-

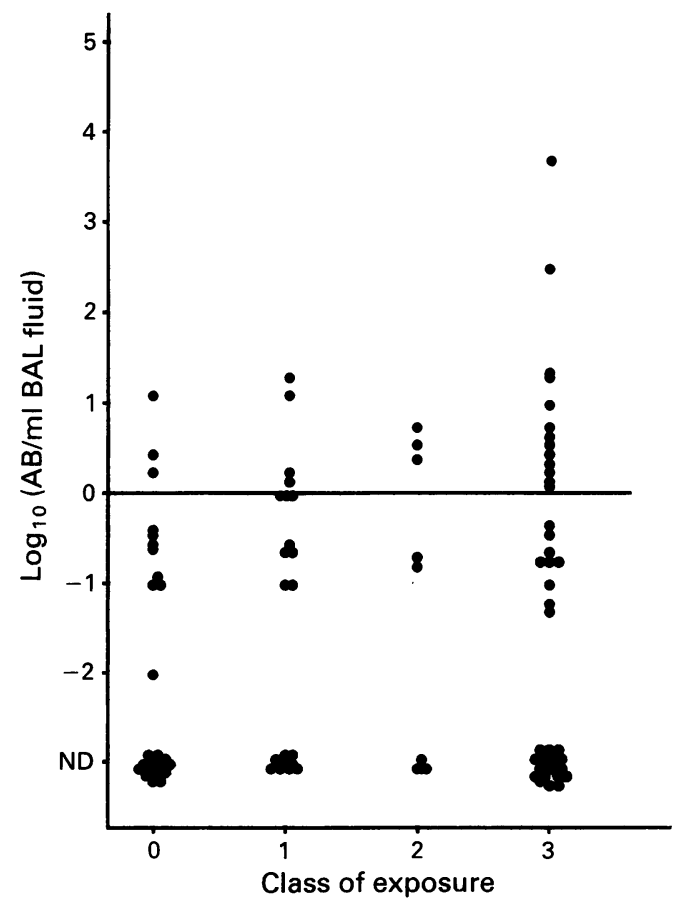

Figure 1 Distribution of asbestos bodies $(A B)$ as $\log _{10}(A B / \mathrm{ml})$ in $B A L$ fluid samples in various classes of asbestos exposure. Each point indicates result of the $A B$ count for one subject. Horizontal line corresponds to the threshold value of significant retention of $A B$ predictive of non-trivial asbestos exposure $\left(1 \mathrm{AB} / \mathrm{ml}\right.$ in $B A L F ; \log _{10}$ $(A B / m l)=0) . N D=$ not detected. nificant difference was shown in asbestos body count in BAL fluid between the different classes of exposure. By contrast, analysis of lung tissue showed a significant difference between the four classes of exposure, class 3 showing the highest asbestos body load, as expected. Figures 1 and 2 show the distributions of individual counts of asbestos bodies among the various classes of exposure for BAL fluid and lung tissue samples. A considerable overlap was noted between the four classes of exposure for BAL fluid samples, and for classes 0,1 , and 2 for lung tissue samples.

Table 3 shows, for each class of exposure,

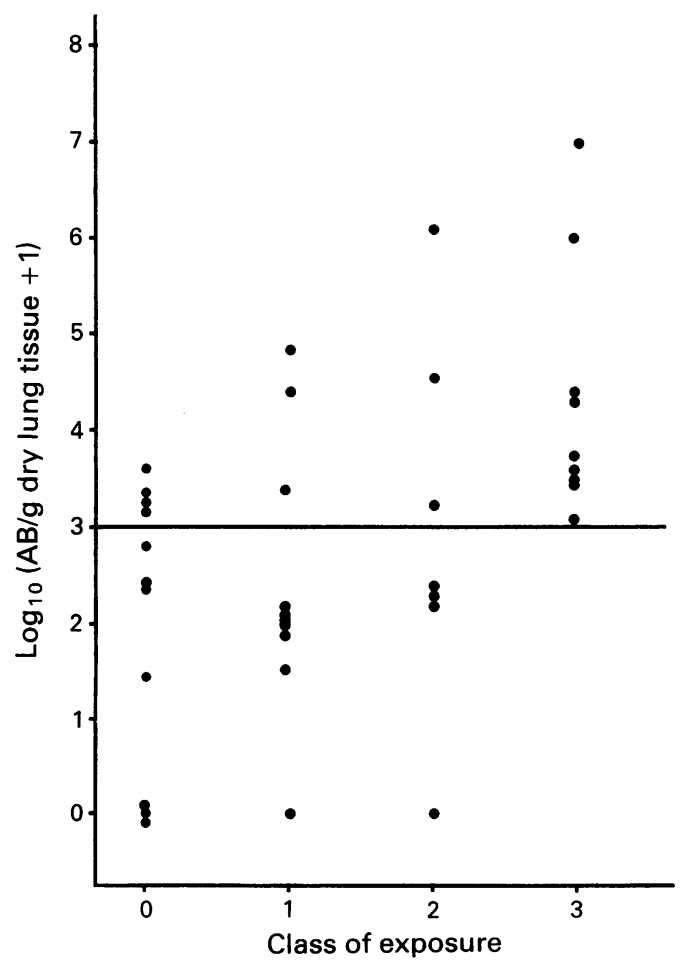

Figure 2 Distribution of asbestos bodies $(A B)$ as $\log _{10}$ (AB/g of dry lung tissue +1 ) in lung tissue samples in various classes of asbestos exposure. Each point indicates result of the $A B$ count for one subject. Horizontal line corresponds to the threshold value of significant retention of $A B$ predictive of non-trivial asbestos exposure $(1000 \mathrm{AB} / \mathrm{g}$ of dry lung tissue; $\left.\log _{10}(A B / g+1)=3\right)$. 
Table 3 Percentage of subjects showing significant retention of asbestos bodies in $B A L$ fluid or lung tissue

\begin{tabular}{|c|c|c|c|c|c|c|}
\hline \multirow{2}{*}{$\begin{array}{l}\text { Grade of } \\
\text { exposure }\end{array}$} & \multicolumn{2}{|c|}{$\begin{array}{l}\text { BAL fluid or lung } \\
\text { tissue samples }\end{array}$} & \multicolumn{2}{|c|}{$\begin{array}{l}\text { BAL fluid } \\
\text { samples }\end{array}$} & \multicolumn{2}{|c|}{$\begin{array}{l}\text { Tissue } \\
\text { samples }\end{array}$} \\
\hline & No & $H R \% \star$ & No & $H R \%^{\star}$ & No & $H R \%^{\star}$ \\
\hline Whole sample & 131 & $34 \cdot 4$ & 95 & $27 \cdot 4$ & 36 & $52 \cdot 8$ \\
\hline Class 0 & 36 & $19 \cdot 4$ & 25 & 12 & 11 & $36 \cdot 4$ \\
\hline Class 1 & 31 & $32 \cdot 3$ & 22 & $31 \cdot 8$ & 9 & $33 \cdot 3$ \\
\hline Class 2 & 16 & $37 \cdot 5$ & 9 & $33 \cdot 3$ & 7 & $42 \cdot 9$ \\
\hline Class 3 & 48 & $45 \cdot 8$ & 39 & $33 \cdot 3$ & 9 & \\
\hline $\mathrm{p}$ Valuet & & 0.09 & & NS & & $<0.05$ \\
\hline
\end{tabular}

«Percentage of subjects exhibiting significant retention of asbestos bodies in the biologica sample; threshold values of significant retention of asbestos bodies predictive of non-trivia asbestos exposure were one asbestos body/ml of BAL fluid and 1000 asbestos bodies/g of dry lung tissue.

†Comparison of subjects of all classes by $\chi^{2}$ test.

the proportion of subjects with an asbestos body count above the threshold value in BAL fluid or lung tissue. Two thirds of subjects showed no significant retention of asbestos bodies in the lung. As expected, class 3 was associated with a significantly higher proportion of HR subjects than classes 0,1 and 2 .

No significant correlation was found between asbestos body count in BAL fluid or lung tissue samples and cumulative duration of exposure to asbestos ( $\mathrm{r}=0.11$ for $\mathrm{BAL}$ fluid and 0.33 for lung tissue samples), or between asbestos body count and time elapsed since the end of exposure to asbestos ( $r=0.08$ for BAL fluid and -0.31 for lung tissue samples). When this correlation analysis was restricted to subjects belonging to class 3 , a reduction in asbestos body count was noted with increasing time since the end of exposure $(r=-0.31, p=0.053$ for BAL fluid and $r=-0.53, \mathrm{p}=0.13$ for lung tissue samples).

\section{Discussion}

Our results showed that only a few patients with mesothelioma had experienced significant occupational exposure to asbestos. Class 3 subjects represented only $36.6 \%$ of all subjects, and only $34.4 \%$ of the subjects had asbestos body counts above threshold values in BAL fluid or lung tissue. Moreover, 29 subjects $(22 \cdot 1 \%)$ had no history of exposure to asbestos at all and no significant retention of asbestos bodies in BAL fluid or in lung tissue. Previously published case-control studies on mesothelioma have shown considerable variations in the percentage of subjects exposed to asbestos, from $5 \%$ to $88 \%$, whereas the percentage of non-exposed referent subjects was reported to vary between $52 \%$ and $98 \% .^{3}$ This could be partly explained by different ways of assessing exposure to asbestos. Some authors have stressed that self reported exposure to asbestos could lead to erroneous conclusions with subsequent poor reproducibility in assessing exposure for a given job title. ${ }^{14} \mathrm{We}$ determined the history of exposure to asbestos in our subjects by means of an interview, completed by the evaluation of two experts. Apart from information mentioned in the questionnaire, they also took into account knowledge of exposure in similar occupational settings at the same period. Thus heterogeneity of the patient's knowledge about previous exposure to asbestos was probably minimised.
A more objective assessment was provided by metrology of asbestos bodies in BAL fluid or lung tissue by light microscopy. Studies of asbestos body counts in BAL fluid or lung tissue with a light microscope have given contrasting results in series of patients with malignant mesothelioma. ${ }^{18-21}$ 23-26 In many reports, cases were recruited in regions with heavy use of asbestos, leading to an overrepresentation of heavily exposed subjects. Moreover, in some studies it cannot be ascertained that subjects undergoing asbestos body counts in lung tissue were representative of all mesotheliomas occurring during the same period. Thus Gaudichet et al concluded that $70 \%$ of their cases had retention of asbestos bodies in the lung of more than $10^{3} / \mathrm{g}$ of dry lung tissue, but most of these subjects were former shipyard workers. Kishimoto reported $100 \%$ of subjects with significant retention of asbestos bodies in the lung in a series of 19 cases of mesothelioma in a city close to shipyards $^{23}$; similarly, Bianchi et al found that 34 out of 36 mesothelioma cases previously employed in the shipbuilding industry had more than $10^{3}$ asbestos bodies/g of dry lung tissue. ${ }^{19}$ Roggli et al reported that 10 out of 15 cases of mesothelioma without associated asbestosis had significant exposure to asbestos, on the basis of asbestos body counts in wet lung tissue. ${ }^{18}$ More than half of these workers had been employed as insulators or in shipyards. In the study by Warnock, all 27 cases of mesothelioma were found to have a history of exposure to asbestos, mainly in shipyards or in the construction industry, and 26 of them had retention of asbestos bodies in the lung of more than $10^{3} / \mathrm{g}$ of dry lung tissue. ${ }^{21}$ By contrast, fewer studies have been published in series of cases of mesothelioma with less obvious heavy exposure to asbestos. In a series of 36 cases, Hirsch et al ${ }^{24}$ found that 18 out of 28 subjects undergoing asbestos body counts in sputum, BAL fluid, or lung tissue had results suggesting significant retention of asbestos bodies in the lung. ${ }^{24}$ In a series of 25 consecutive cases, Roggli et al showed that only nine of them had significant retention of asbestos bodies in the lung. ${ }^{25}$ Murai and Kitagawa reported that only 14 out of 27 cases of mesothelioma in a general population showed retention of asbestos bodies above the threshold value of significant retention. ${ }^{26}$ Counting asbestos bodies with a light microscope in our study showed the proportion of significant retention of asbestos bodies in the lung to be among the lowest values previously reported for similar methods. This was partly explained by the fact that our subjects originated from the Paris area in which there are few asbestos transforming industries. We do not consider that the inclusion criteria used here would have biased the results towards underestimation of retention of asbestos bodies in the lung in subjects with mesothelioma. Indeed, preliminary analysis of our data in the case-control study has shown that the group of cases without an asbestos body count in BAL fluid or lung tissue had a higher proportion of subjects without exposure 
to asbestos than the group of cases undergoing an asbestos body count, as assessed by analysis of job history (data not shown). As a good agreement between the asbestos body count in BAL fluid and in lung tissue has been reported, ${ }^{17}$ we considered both results as pertinent with regard to retention of asbestos bodies. The proportion of subjects, however, exhibiting significant asbestos body retention in BAL fluid was lower than that found in lung tissue. Despite good reproducibility, some authors have previously reported that counts of asbestos bodies in BAL fluid were poorly related to measures of exposure. ${ }^{31}$ This emphasises the fact that analysis of lung tissue remains the gold standard.

Although some authors have shown biopersistence of asbestos bodies in the lower respiratory tract of humans from results of repeated $\mathrm{BAL}$, ${ }^{32}$ we cannot exclude the possibility of a certain amount of clearance of asbestos bodies with increasing time since the end of exposure. This is in agreement with the exponential clearance scheme previously described for fibres, ${ }^{6}$ and would explain that non-significant retention of asbestos bodies can be found in subjects with initial moderate retention of asbestos bodies in the lung. The long period of time since the end of exposure (median: 20 years in class 1, 25 years in class 2 , and 15.5 years in class 3 ) and the tendency to a decreasing asbestos body count in BAL fluid or lung tissue with increasing time since the end of exposure are in favour of this hypothesis. This raised the question of the relevance of the threshold values of the asbestos body count indicative of non-trivial exposure to asbestos, ${ }^{17}$ in cases of mesothelioma where exposure to asbestos ended one or more decades ago. Two elements did not suggest that a lower threshold would improve sensitivity of detection of exposure in this study: the overlap of asbestos body concentrations among the various classes of exposure (figs 1 and 2 ) and the number of subjects with asbestos body concentrations far below the adopted threshold values in BAL fluid $(1.0 / \mathrm{ml} ; 14$ subjects in class 0,10 subjects in class 1 , five subjects in class 2 , and 16 subjects in class 3 were below $0 \cdot 1 / \mathrm{ml}$ ) or lung tissue $(1000 / g$ of dry lung tissue; four subjects in class 0 , two subjects in class 1 , one subject in class 2 and none in class 3 were below $100 / \mathrm{g}$ dry lung tissue). This was in agreement with the hypothesis of a biphasic distribution of the logarithm of asbestos body counts in patients with mesothelioma, which was previously described by other authors, ${ }^{33}$ the first distribution (suggestive of low levels of asbestos body retention in the lung) overlapping values encountered in the general population.

Results of counting uncoated fibres by transmission electron microscopy in lung tissue were not available in this series. This would undoubtedly be useful to better assess lung fibre load in this group of mesotheliomas with a history of generally low exposure to asbestos. In our experience, transmission electron microscopy has given counts of uncoated fibres consistent with those of asbestos bodies obtained with a light microscope. ${ }^{34}$ In a series of 52 patients with different asbestos induced diseases (42 were mesotheliomas), $75 \%$ of results were concordant for both methods. Nineteen per cent exhibited non-significant retention of asbestos bodies, but counts of uncoated fibres showed results above $10^{6}$ fibres $/ g$ of dry lung tissue. The agreement between results of transmission electron and light microscopy was better when the analysis was restricted to fibres longer than $5 \mu \mathrm{m}$, which are considered to be the threshold size in terms of capacity to induce mesotheliomas with only $7 \%$ of cases showing high retention of uncoated fibres and low level of retention of asbestos bodies. Numerous other studies have reported good correlations between fibre counts (mainly amphiboles) obtained by electron microscopy (scanning or transmission) and asbestos body counts obtained by light microscopy in mesothelioma series ${ }^{182126}$ or other diseases. ${ }^{35-38}$ This indicates that in most cases light microscopy could be recommended for evaluation of lung fibre burden in cases of mesothelioma, because it is a much easier method. Analysis by electron microscopy could be restricted to those cases in which the light microscope indicates a non-significant retention of asbestos bodies, especially in cases without an obvious history of exposure to asbestos. ${ }^{12}$

\section{Conclusion}

Low indices of exposure to asbestos were found in this series of patients with mesotheliomas recruited in a region with few asbestos transforming industries, when data from a questionnaire and results of an asbestos body count in BAL fluid or lung tissue were used. This raises the question of the relevance of the usual threshold values of retention of asbestos bodies in these biological samples for cases of mesothelioma, and emphasises the usefulness of transmission electron microscopy to better quantify lung retention of asbestos fibres. The role of low cumulative exposure (either continuous exposure to low levels or sporadic peak exposure) or other aetiological factors remains to be elucidated.

Appendix

OF JOBS THAT DETERMINED THE CLASSIFICATION OF THE Class 0

Clerical jobs; machinery fitter in aircraft manufacture Machine tool operator (in industries other than shipbuilding or asbestos processing); merchant; cabinet maker; farmer; or asbestos processing); merchant; cabinet maker; farmer; nurse; paper manufacture worker; baker; labourer (construcradiator manufacture; presser (home help); dressmaker; tailor; radiator manufacture; presser (home help); dressmaker; tail
packer of printed papers; shopkeeper (grocery); postman.

Class 1

Sheet metal worker in chemical industry; sheet metal worker in a power station; sheet metal worker in the construction industry; building site mechanic; welder; pottery worker; cable layer; plumber; maintenance worker in power plant; presser (laundry); laundry maintenance worker; engineer in railway (laundry); laundry maintenance worker; engineer in railway
equipment manufacture; lighting technician; steel industry equipment manufacture; lighting technician; steel industry
maintenance worker; draughtsman in oven manufacture; maintenance worker; draughtsman in oven manufacture;
worker in manufacture of hydraulic press; technician in the worker in manufacture
petrochemical industry. 
Class 2

Unskilled foundry worker; unskilled glass manufacture worker; sheet metal worker in a railway repair shop; ironmonger; mason; building electrician ; car mechanic; motor vehicle electrician; building joiner; draughtsman in production of compressed gas.

Class 3

Asbestos sprayer; fibrous plasterer; constructional steel erector; construction sheet metal worker; marine engine mechanic; ship's electrician; foreman in the plastic industry; boiler fireman; lathe operator in asbestos cement factory; boiler fireman; lathe operator in asbestos cement factory; worker in asbestos-textile manufacture; gas boiler repairman; worker in brake lining manufacture; engineer in brake-lining
manufacture; welder in furnace manufacture; glass blower; machine operator in glass manufacture; plate glass rollerman railroad car joiner; locomotive repairman; worker in manufacture of railroad equipment; electrician in a power station ${ }^{\star}$ electrician in a cement factory; chemist in nuclear energy production; pipe fitter in production of compressed gas; aircraft sheetmetal worker; boiler maintenance worker; maintenance electrician, manufacture of plastic insulation material; firebrick layer; ceiling maker; lift installer; maintenance worker in steel manufacture; worker in machine tool construction; sheet metal worker in production of compressed gas; machine fitter metal worker in production of compressed gas; machine fitter
in a steam locomotive repairshop; store room clerk, power stain a s.
tion.

*According to task description this occupation was assigned to class 1 in one specific case.

1 Gibbs AR. Role of asbestos and other fibres in the development of diffuse malignant mesothelioma. Thorax 1990;45:649-54.

2 McDonald JC, McDonald AD. Epidemiology of mesothelioma. In: Liddell $\mathrm{D}$, Miller $\mathrm{K}$, eds. Mineral fibres and health. London: CRC Press, 1991, 147-68.

3 Brochard P, Pairon JC, Iwatsubo Y, Bignon J. Workrelated mesothelioma. European Respiratory Review 1993;3:74-8.

4 Liddell D. Health effects of historical exposures to asbestos. In: Gibbs $G$, Dunnigan J, Kido M, Higashi $T$, eds. Health risks from exposure to mineral fibres: an interna tional perspective. North York, Ontario: Captus (in press).

5 Jones JSP, Roberts GH, Pooley FD, Clark NJ, Smith PG, Owen WG, et al. The pathology and mineral content of lungs in cases of mesothelioma in the United Kingdom in 1976. In Wagner JC, Biological effects of mineral fibres. Lyon: International Agency for Research on Cancer, Lyon: International Agency

6 Berry G, Rogers AJ, Pooley FD. Mesotheliomas-asbestos exposure and lung burden. In: Bignon J, Peto J, Saracci $\mathrm{R}$, eds. Non occupational exposure to mineral fibres. Lyon: International Agency for Research on Cancer, 1989:486-96. Sci publ No 90.

7 Churg A, Wright JL. Fibre content of lung in amphiboleand chrysotile-induced mesothelioma: implications fo environmental exposure. In: Bignon J, Peto J, Saracci R, eds. Non occupational exposure to mineral fibres. Lyon: International Agency for Research on Cancer, 1989: 314-8. Sci Publ No 90 .

8 McDonald JC, Armstrong B, Case B, Doell D, McCaughey WTE, McDonald AD, Sebastien $P$ Mesothelioma and asbestos fiber type. Evidence from lung tissue analyses. Cancer 1989;63:1544-7.

9 Friedrichs $\mathrm{KH}$, Brockmann $M$, Fischer M, Wick G. Electron microscopy analysis of mineral fibers in human lung tissue. Am $\mathcal{F}$ Ind Med 1992;22:49-58.

10 Tammilehto $\mathrm{L}$, Tuomi $\mathrm{T}$, Tiainen $\mathrm{M}$, Rautonen $\mathrm{J}$, Knuutila S, Pyrhönen S, Mattson K. Malignant mesothelioma: clinical characteristics, asbestos mineralogy and chromosomal abnormalities of 41 patients. Eur fCancer 1992;28:1373-9.

11 Roggli VL, Pratt PC, Brody AR. Asbestos fiber type in malignant mesothelioma: an analytical scanning elec-
tron microscopic study of 94 cases. Am $\mathcal{F}$ Ind Med tron microscopic

12 Gibbs AR, Jones JSP, Pooley FD, Griffith DM, Wagner JC. Non-occupational malignant mesotheliomas. In Bignon J, Peto J Saracci R, eds. Non-occupational exposure to mineral fibres. Lyon: International Agency fo Research on Cancer, 1989:219-28. Sci Publ No 90.

13 Valleron A-J, Bignon J, Hughes JM, Hesterberg TW, Schneider T, Burdett GJ, et al. Low dose exposure to natural and man made fibres and the risk of cancer: towards a collaborative European epidemiology. Report of a workshop held in Paris, 10-12 June, 1991. Brf Ind Med 1992;49:606-14.

14 Holmes E, Garshick E. The reproducibility of the selfreport of occupational exposure to asbestos and dust. report of occupational exposur

15 Orlowski E, Hermann Pohlabeln H, Berrino F, Ahrens W, Bolm-Audorff U, Grossgarten K, et al. Retrospective
assessment of asbestos exposure.II. At the job level: complementarity of job specific questionnaire and jobexposure matrices. Int $\mathcal{f}$ Epidemiol 1993 (in press)

16 De Vuyst P, Dumortier P, Moulin E, Yourassowsky N, Yernault JC. Diagnostic value of asbestos bodies in bronchoalveolar lavage fluid. Am Rev Respir Dis 1987; 136:1219-24.

17 Sebastien P, Armstrong B, Monchaux G, Bignon J. Asbestos bodies in bronchoalveolar lavage fluid and in lung parenchyma. Am Rev Respir Dis 1988;137:75-8.

18 Roggli VL, Pratt PC, Brody AR. Asbestos content of lung tissue in asbestos associated diseases: a study of 110 cases. $\mathrm{Br} \mathcal{F}$ Ind $\mathrm{Med}$ 1986;43:18-28.

19 Bianchi C, Brollo A, Ramani L. Malignant pleural mesothelioma in Monfalcone, Italy. Proceedings of the VIIth International Pneumoconiosis Conference. Pittsburg Pennsylvania: National Institute for Occupational Safety and Health - International Labour Office, 1988:1441-5.

20 Gaudichet A, Janson X, Monchaux G, Dufour G, Sebastien P, De Lajartre AY, Bignon J. Assessment by analytical microscopy of the total lung fibre burden in mesothelioma patients matched with four other pathological series. Ann Occup Hyg 1988;32(suppl 1):213-23.

21 Warnock ML. Lung asbestos burden in shipyard and construction workers with mesothelioma: comparison with burdens in subjects with asbestosis or lung cancer. Environ Res 1989;50:68-85.

22 Rogers AJ, Leigh J, Berry G, Ferguson DA, Mulder HB Ackad M. Relationship between lung asbestos fiber type and concentration and relative risk of mesothelioma. A case-control study. Cancer 1991;67:1912-20.

23 Kishimoto T. Cancer due to asbestos exposure. Chest 1992;101:58-63.

24 Hirsch A, Brochard P, De Cremoux H, Erkan L Sebastien P, Di Menza L, Bignon J. Features of asbestos-exposed and unexposed mesothelioma. $\mathrm{Am} \mathcal{F}$ Ind Med 1982;3:413-22.

25 Roggli VL, McGavran MH, Subach J, Sybers HD Greenberg SD. Pulmonary asbestos body counts and electron probe analysis of asbestos body cores in patients with mesothelioma. A study of 25 cases. Cancer patients with meso

26 Murai Y, Kitagawa M. Asbestos fiber analysis in 27 malignant mesothelioma cases. Am f Ind Med 1992;22: 193-207.

27 Bignon J, Sebastien P, Di Menza L, Nebut M, Payan H French mesothelioma register. Ann NY Acad Sci 1979;330:455-66.

28 Siemiatycki J, Dewar J, Lakhami R, Nadon L, Richardson $L$, Gerin $M$. Cancer risks associated with 10 inorganic dusts: results from a case-control study in Montreal. $\mathrm{Am}$ dusts: results from a case-con $1989 ; 16: 547-67$.

29 Churg A, Warnock ML. Analysis of the cores of ferruginous (asbestos) bodies from the general population.I. Patients with and without lung cancer. Lab Invest 1977; 37:280-6.

30 Churg AM Warnock ML. Analysis of the cores of ferruginous (asbestos) bodies from the general population. III Patients with environmental exposure. Lab Invest 1979;40:622-6.

31 Schwartz DA, Galvin JR, Burmeister LF, Merchant RK, Dayton CS, Merchant JA, Hunninghake GW. The clinical utility and reliability of asbestos bodies in bronchoalveolar lavage fluid. Am Rev Respir Dis 1991;144: 684-8.

32 Gaudichet A, Brochard P, Bignon J. Analyse minéralogique des produits de lavage broncho-alvéo$\mathrm{M}^{\mathbf{5}}: 1-8$.

33 Roggli VL. Quantitative and analytical studies in the diagnosis of mesothelioma. Semin Diagn Pathol 1992;9: 162-8.

34 Martinon L, Billon-Galland MA, Janson X, Pairon JC, Iwatsubo Y, Brochard P. Assessment of asbestos pulmonary retention: relationship between asbestos bodies determined by optical microscopy and uncoated asbestos fibres determined by analytical transmission electron microscopy. Proceedings of the VIIIth international conference on occupational lung diseases. Prague, tional conference on occupational lung diseases. Prague, 14-17 September. 1992.

35 Dodson RF, Williams MG, O'Sullivan MF, Corn CJ Greenberg SD, Hurst GA. A comparison of the ferruginous body and uncoated fiber content in the lungs of former asbestos workers. Am Rev Respir Dis 1985;132. 143-7.

36 Warnock ML, Wolery G. Asbestos bodies or fibers and the diagnosis of asbestosis. Environ Res 1987;44:29-44.

37 Dodson RF, Garcia JGN, O'Sullivan M, Corn C, Levin JL, Griffith DE, Kronenberg RS. The usefulness of bronchoalveolar lavage in identifying past occupational exposure to asbestos: a light and electron microscopy exposure to asbestos: a light and electr.

38 Tuomi T, Oksa P, Anttila S, Taikina-Aho O, Taskinen E Karjailainen A, Tukiainen P. Fibres and asbestos bodies in bronchoalveolar lavage fluids of asbestos sprayers. $\mathrm{Br}$ in Ind Med 1992;49:480-5. 